\title{
The enteric nervous system in intestinal inflammation
}

\author{
KeIth A SHARKEY PhD, EDWARd J PARR BSc
}

\begin{abstract}
KA SHARKEY, EJ PARR. The enteric nervous system in intestinal inflammation. Can J Gastroenterol 1996;10(5):335-341. Since about the 1950s nerves in the wall of the intestine have been postulated to play a role in the pathogenesis of inflammatory bowel disease (IBD). Human and animal studies examining the role of nerves in intestinal inflammation are the focus of this review. Consideration is given to two possible ways that nerves are involved in IBD. First, nerves may play a role in the development or maintenance of inflammation through local release of transmitters. Second, once initiated (by whatever means), the processes of inflammation may disrupt the normal pattern of innervation and the interactions of nerves and their target tissues. Many of the functional disturbances observed in IBD are likely due to an alteration in the enteric nervous system either structurally through disruptions of nerve-target relationships or by modifications of neurotransmitters or their receptors. Finally, it appears that the enteric nervous system may be a potential therapeutic target in IBD and that neuroactive drugs acting locally can represent useful agents in the management of this disease.
\end{abstract}

Key Words: Capsaicin, Crohn's disease, Enteric nervous system, Inflammation, Neurogenic inflammation, Peptides, Substance P, Ulcerative colitis, Vasoactive intestinal polypeptide

\section{Le système nerveux entérique dans l'inflammation intestinale}

RÉSUMÉ : Depuis environ 1950, on estime que les nerfs de la paroi intestinale jouent un rôle dans la pathogenèse de la maladie inflammatoire de l'intestin (MII). Des études sur des sujets humains et sur des animaux se sont penchées sur le rôle des nerfs dans l'inflammation intestinale. Le présent article en fait le bilan. Les nerfs peuvent influer de deux façons sur les MII. Tout d'abord, les nerfs jouent un rôle dans l'installation ou le maintien de l'inflammation par la libération locale de neurotransmetteurs. Ensuite, une fois déclenchés (peu importe de quelle façon), les processus inflammatoires peuvent perturber le mode normal d'innervation et d'interaction des nerfs et de leurs tissus cibles. De nombreuses anomalies fonctionnelles observées dans les MII sont probablement dues à une altération du système nerveux entérique, soit sur le plan de la structure à cause de la perturbation des liens entre les nerfs et leurs cibles, soit sur le plan des modifications affectant les neurotransmetteurs ou leurs récepteurs. Finalement, il semble que le système nerveux entérique puisse être une cible thérapeutique dans les MII et que les médicaments neuroactifs à action locale puissent être utiles dans le traitement de cette maladie.
$S^{i}$ ince about the 1950s nerves in the wall of the intestine have been postulated to play a role in the pathogenesis of inflammatory bowel disease (IBD). Storsteen and colleagues (1) were the first to demonstrate that enteric neurons were involved in this process by providing histological evidence for an increased number of myenteric ganglion cells in chronic ulcerative colitis. Similar observations were also made in Crohn's disease (2). Extrinsic nerves innervating the bowel have also been implicated in IBD based not only on the common observation of abdominal pain in IBD, but also on clinical observations that vagotomy and pelvic nerve lesions could modify, and in some cases improve, the outcome of IBD (3-5). Additionally, autonomic neuropathy has been described in IBD and might contribute to IBD symptoms $(6,7)$. Although surgical denervation is no longer used for the therapeutic management of IBD, the role of nerves in this multifactorial disease has become established. Human and animal studies examining the role of nerves in intestinal inflammation are the focus of this review. Consid-

Neuroscience and Gastrointestinal Research Groups, Department of Medical Physiology, The University of Calgary, Calgary, Alberta

Correspondence and reprints: Dr Keith Sharkey, Department of Physiology and Biophysics, The University of Calgary, 3330 Hospital Drive NW, Calgary, Alberta T2N 4N1. Telephone 403-220-4601, fax 403-283-8731, e-mail ksharkey@acs.ucalgary.ca

This paper was presented at the Basic Research and Clinical Implications in IBD meeting, April 6 to 9, 1994, held in Victoria, British Columbia. This paper has also been published in Sutherland LR, et al, eds. Inflammatory Bowel Disease: Basic Research, Clinical Implications and Trends in Therapy. Boston, Dordrecht and London: Kluwer Academic Publishers, 1994 

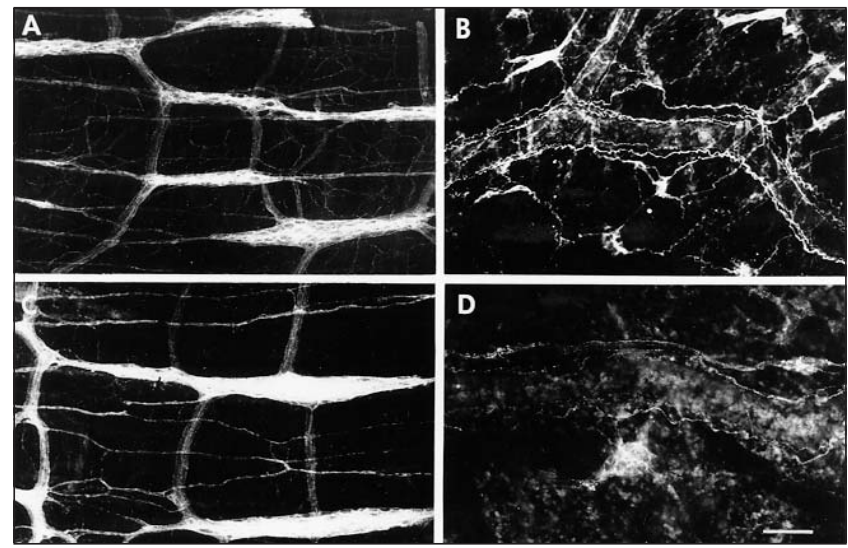

Figure 1) Fluorescence micrographs of substance P immunoreactivity (SP-IR) in whole mount preparations of the myenteric plexus (A and C) and submucosa (B and D) from the guinea-pig ileum. A,B Shamoperated controls. C,D Twenty-four hours after a single intraluminal injection of trinitrobenzene sulphonic acid. Note that $24 \mathrm{~h}$ after the induction of inflammation there was a substantial reduction in SP-IR in the submucosa, particularly that associated with blood vessels. No reduction, and possibly a slight increase, in SP-IR was observed in the myenteric plexus. Full details are provided in reference 22. Scale bar: $100 \mu \mathrm{m}$. Reproduced with permission from reference 22

eration will be given to two possible ways that nerves are involved in IBD. First, nerves may play a role in the development or maintenance of inflammation through local release of transmitters. Second, once initiated (by whatever means), the processes of inflammation may disrupt the normal pattern of innervation and the interactions of nerves and their target tissues. Finally, the role of the central nervous system in modulation of immune function must be acknowledged, but it is outside the scope of this review to consider this aspect of the nervous regulation of inflammation.

\section{INNERVATION OF THE GASTROINTESTINAL TRACT}

The gastrointestinal tract is innervated by extrinsic sympathetic and parasympathetic autonomic nerves, primary afferent fibres that follow the course of the autonomic nerves and enteric nerves (8). Although extrinsic nerves innervating the bowel are thought of as largely efferent, the majority are afferent (9). These nerves respond to noxious mechanical and chemical stimulation, and are mostly sensitive to the selective sensory neurotoxin capsaicin (9-11). These nerves contain a number of biologically active peptides, in particular substance $\mathrm{P}$ and calcitonin gene-related peptide (CGRP) (12). The local release of these peptides from the peripheral terminals of primary afferents gives rise to neurogenic inflammation (13), which causes effects such as local vasodilation, plasma protein extravasation and mast cell degranulation. The contribution that primary afferents make to inflammatory processes in the gastrointestinal tract is not clear due to, in part, the complexity of intestinal innervation and the fact that many transmitters found in primary afferents are also present in enteric nerves.
The enteric nervous system (ENS) consists of two interconnected ganglionated plexuses and an extensive fibre and terminal network that innervates all components of the bowel wall (8). The ganglionated plexuses lie between the longitudinal and circular muscle layers (myenteric plexus) and in the submucosa (submucous plexus). The observation that a single enteric neuron may contain more than one transmitter or neuron-specific marker has led to the concept of chemical coding of enteric neurons (14). This process has been so successful in the guinea-pig ileum that apparently all neurons in both plexuses have been accounted for (14-16). However, because this detailed coding has not been fully explored in many other regions or in other species, its true value or applicability is limited. Chemical coding has recently been extended further by combining studies based on the projections of identified neurons, and coupling these combinations with their electrophysiological classification (15-17). Taken together, a structural and functional mapping of the guinea-pig ileum has been achieved. Thus, by visualizing identified cell types, inferences can be made about their function, and changes in the number or proportion of given cells may indicate altered function.

Neurons in the ENS are in a unique environment. They are regularly distorted by peristaltic contractions, the wall of the gut contains a resident population of inflammatory cells that contribute to a physiological state of basal (low level) inflammation and there is constant remodelling of the mucosa due to epithelial sloughing, which includes remodelling of the neural connections. This environment leads to a cell phenotype that differs substantially from other autonomic neurons. For example, work from the author's laboratory has recently shown that enteric neurons constitutively express high levels of the protein B-50 (18) and certain protooncogene products such as fos and myc $(19,20)$.

\section{ENTERIC INNERVATION IN INFLAMMATION - ANIMAL STUDIES}

Peptides: Much of the work in animal models of gastrointestinal inflammation has focused on substance $P$ because of its role as a mediator of neurogenic inflammation (21). Using a hapten-induced model of ileitis (intraluminal injection of trinitrobenzene sulphonic acid [TNBS]) it was shown that the pattern of substance P immunoreactivity in the submucosa of the guinea-pig ileum is modified (22). Substance $\mathrm{P}$ in the ileum is in primary afferent and enteric nerves; the former (detected on the basis of their location around blood vessels) appears particularly affected. There is an initial reduction in substance $\mathrm{P}$ by $24 \mathrm{~h}$ (Figure 1) consistent with sustained release, followed by a gradual increase in the intensity and density of immunoreactive nerves and an increased quantity of substance $P$, first in enteric nerves and later in primary afferent nerves until the pattern of innervation returns to normal 21 to 30 days later.

Substance P and CGRP in rabbit colitis or ferret jejunitis/ileitis models were found to be reduced up to $48 \mathrm{~h}$ after induction of inflammation $(23,24)$. In the rabbit it was also found that the density and intensity of immunoreactivity 
were reduced, although the overall pattern of nerves was similar in inflamed and control animals (24).

In jejunitis due to Trichinella spiralis infection, Swain et al (25) showed that substance P levels were increased in the myenteric plexus up to six days postinfection. This increase was abolished in capsaicin-treated rats, indicating a primary afferent origin of substance P. It was also abolished in congenitally athymic rats, which suggests that $\mathrm{T}$ lymphocytes play some role in the increase, probably through release of cytokines. Hurst and co-workers (26) followed up that observation to demonstrate that interleukin-1-beta was involved in the increase in substance $P$, which was found to be exclusively neuronal (26). The cellular mechanisms and inflammatory cell types underlying this neuroimmune interaction in the myenteric plexus have yet to be elucidated, and whether similar mechanisms apply to the submucous plexus is unknown.

Sharkey and Ihns (27) have provided preliminary evidence that the number of vasoactive intestinal polypeptide (VIP) immunoreactive neurons in the submucous plexus of the guinea-pig were not affected in TNBS-induced ileitis and that VIP-containing neurons in the myenteric plexus were actually increased. Similarly, Kishimoto et al (28) observed an increased VIP immunoreactivity in neurons and fibres in both plexuses of the colon and an elevated content of VIP in dextran sulphate-induced colitis in rats. Interestingly, these increases are consistent with preliminary reports of increased VIP mRNA in IBD in humans (29).

Capsaicin-sensitive nerves: In intestinal inflammation there are only a few studies that have examined the role of capsaicin-sensitive nerves (12). In rats with colitis induced with TNBS, acetic acid or dextran sulphate sodium, neonatal capsaicin treatment augments damage after induction of inflammation (30-33). This suggests that primary afferent nerves are involved in aspects of restoration of mucosal integrity in 'chronic' inflammation; however, further confirmation and extension of these data are required.

In rats sensitized to egg albumin, neonatal capsaicin treatment reduced the short circuit current responses (an indicator of active chloride secretion) to antigen challenge by about 50\% (34). This implies a role for these nerves in the regulation of secretory events in inflammation. Because a mast cell stabilizer also blocked secretion induced by antigen challenge, some of the effects of nerves may be mediated through a nerve-mast cell interaction (34). Secretion is an important physiological defence mechanism to luminal irritants (or inflammatory agents). MacNaughton et al (35) examined some aspects of the neural control of secretory events and showed that mast cells are essential for nervemediated chloride secretion in the rat ileum in uninflamed tissues. Another important secretory product is mucin, which acts as a physical defence mechanism and whose release is enhanced in inflammation (36). It has now been demonstrated that capsaicin-sensitive nerves are involved in the neural regulation of mucin secretion $(37,38)$.

Transmitters and receptors: The role of neurotransmitter receptors in inflammation, which until recently lacked at- tention, was examined by Martinolle and colleagues (30). They examined the regulation of adrenergic receptors on smooth muscle/myenteric plexus preparations of guinea-pig jejunum and found that alpha ${ }_{1}$ - and alpha ${ }_{2}$-adrenergic receptors were upregulated 10 days after induction of jejunitis with TNBS, whereas beta-adrenergic receptors were downregulated. Those authors suggested that motility disturbances seen in small bowel inflammation might be related to this inverse receptor regulation.

Finally, a few studies have investigated transmitter release from the ENS or its electrophysiological consequences. Both acetylcholine and noradrenaline release are depressed in trichinella-infected rats $(40,41)$. The depression observed in infected animals was mimicked in both cases by preincubation of tissues with interleukin-1-beta, which suggests that it may be the inflammatory mediator of this effect (42). This suggestion is further supported by studies in which an interleukin-1 receptor antagonist was given to infected rats. In this case noradrenaline release was enhanced compared with that in infected controls (42). In contrast to the depressed release of acetylcholine seen in rats, enhanced sensitivity to applied acetylcholine - potentially compensating for the reduced release - was observed in neurons in the myenteric plexus of trichinella-infected guinea-pigs (43). Although it appears that this is not due to marked changes in electrical properties of the neurons, there was a trend towards enhanced excitability of neuronal membranes. In addition, neurons from infected animals showed a marked increase in responsiveness to histamine (43). This led Wood (44) and Frieling (45) to suggest that histamine, released from mast cells, is responsible for many of the observed pathophysiological effects of inflammation through actions at the level of the enteric plexuses.

\section{ENTERIC INNERVATION IN INFLAMMATION - HUMAN STUDIES}

The original observation of increased ganglion cells in the ENS in IBD not only established a neural involvement in these diseases but also initiated a controversy: how can there be more enteric neurons if they are postmitotic? This has not been resolved, but evidence suggests that adult enteric neurons (at least in animals) have a remarkable plasticity of form and the capacity for growth and active DNA synthesis $(46,47)$. Although cell division in adult neurons seems unlikely, it cannot be completely excluded as a possibility; a study in humans found that the number of centrioles in neurons of the submucous plexus was increased in patients with Crohn's disease (48), which may indicate mitosis. Another possible explanation for the observed enteric neuronal hyperplasia is that this disorder is established early in development but does not become clinically apparent until much later in life. This implies that IBD is directly related to a developmental defect that results in abnormal proliferation and survival of enteric neuronal precursors or both. A third possible explanation is that there are precursor cells in enteric ganglia capable of proliferation into neurons. Whether this is true is unknown, but it should be considered given ob- 
servations of the presence of stem cells in the adult central nervous system (49).

In addition to neuronal hyperplasia, ganglion cell and axonal degeneration and necrosis have been observed in IBD (50-52). The pathological abnormalities of IBD appear to depend on the type of IBD (Crohn's disease versus ulcerative colitis), the region of the intestinal wall affected (mucosa versus muscle) and whether the tissue was from a site of active disease (50-52). The damage observed may be immunologically mediated because neurons (and glia) in tissues from Crohn's disease display the major histocompatibility class II antigen on their surface (53). Because this display is important for antigen presentation to $\mathrm{T}$ lymphocytes, it may be linked to nerve response to these inflammatory cells; however, its significance is unclear. Also at the cellular level in Crohn's disease, it appears that there is up-regulation of nerve growth factor in coarse nerve fibres in actively inflamed regions of bowel (54). This may reflect remodelling or regrowth of nerves or their response to inflammatory stimuli.

Several studies examining neuropeptides in the bowel in IBD have found both quantitative and qualitative changes in the innervation. The best studied peptides are VIP and substance P. In the earliest reports, VIP immunoreactive fibres were found to be coarser, thicker and more intensely stained in Crohn's disease compared with tissues from ulcerative colitis or controls $(55,56)$. Associated with this was an increase in VIP content in full wall thickness and biopsy specimens from Crohn's disease. Later studies have not been able to confirm these findings. In one study, VIP immunoreactive nerves were found to be coarser in Crohn's disease compared with controls, but the levels of VIP were not elevated in the ileum and were significantly reduced in the colon (57). In other studies, VIP immunoreactive nerves were reduced in the colon in Crohn's disease (58-60) and ulcerative colitis (60), as was the content of VIP measured by radioimmunoassay (61). Why such differences have been found between studies is not completely clear, but regional variation, disease state and sampling may all contribute. However, real differences may exist because in some of these studies substance $\mathrm{P}$ was also assessed and far fewer discrepancies were noted. In support of the studies that show a reduction in VIP, one report measuring plasma levels of VIP showed a significant positive correlation between VIP levels and disease activity (62). In active disease VIP levels nearly doubled. This increase may indicate a massive and sustained release of VIP in active disease which is consistent with reduced levels detected in tissues, although other explanations are possible.

Substance $\mathrm{P}$ appears to be increased in the mucosa in ulcerative colitis as determined by radioimmunoassay (61, $63,64)$ and by immunohistochemistry $(58)$. In one study this increase was shown to correlate with the extent of inflammation, indicating a potential role of this peptide in ulcerative colitis pathogenesis (64). On the other hand, substance $\mathrm{P}$ appears to be relatively unaffected in Crohn's disease (57, 61). However, it has been demonstrated that receptors for substance $\mathrm{P}$ were up-regulated on blood vessels and lymphoid follicles in Crohn's disease and ulcerative colitis (65).

A few studies have also examined other peptidergic neuronal systems. Enkephalin and bombesin appear to be reduced in Crohn's disease but increased in ulcerative colitis (61). Calcitonin gene-related peptide was reported to be reduced in the muscle layers of resected specimens in Crohn's disease (30). Somatostatin-containing neurons in the submucous plexus were reduced in Crohn's disease but not ulcerative colitis, and this finding was unrelated to the degree of inflammation (66). Reduced levels of somatostatin have been seen in IBD (67), but these reflect both neuronal and enteroendocrine cell pools of the peptide and are thus hard to interpret. Catecholamine-containing nerves are apparently increased in ulcerative colitis $(68,69)$, but tissue catecholamine levels were in one study unaffected (68) and in another increased (70). Finally, there is a preliminary report of up-regulation of nitric oxide synthase in neurons of the submucous and myenteric plexuses in Crohn's disease (71).

\section{INFLAMMATORY CELLS AS TARGETS FOR THE ENTERIC AND AUTONOMIC NERVOUS SYSTEMS}

Mast cells and nerves are found in association with villi of the small intestine $(72,73)$. Stead $(74)$ showed that, in rats infected with a nematode there is remodelling of nerve fibres in the villi associated with changes in mast cell density of the tissue. This implies a structural and presumable functional nerve-mast cell relationship in the bowel, which is supported by studies described above that demonstrate the importance of mast cells in nerve-mediated secretory events. The role of mast cells in models of IBD such as TNBS-treated animals is less clear and their relationships with nerves have yet to be examined. Because the submucosa is an important interface of nerves, mast cells and blood vessels, all of which may play a role in neurogenic inflammation, the relationships of these structures in this region in inflammation deserves examination. In a recent ultrastructural study in IBD patients, Dvorak et al (75) demonstrated that nerve-mast cell associations were significantly increased (as were mast cells) in ulcerative colitis tissues compared with Crohn's disease or control tissues. However, this study showed that the distances between nerves and mast cells were greater than those described in other animal or human studies $(72,73)$. This does not imply that nerves and mast cells were not linked functionally, and further examination of this issue is required.

Other cells, such as macrophages, plasma cells and eosinophils, are probably also involved in neurally mediated responses and are associated with nerves. Macrophages are present in the ENS, and eosinophils and plasma cells have been shown to be innervated in human and animal gastrointestinal tract (76-78).

Another cell type of relevance to inflammation is the lymphocyte. The gastrointestinal tract is a rich source of lymphocytes and indeed plays a vital role in exposure to antigens and in lymphocyte recirculation $(79,80)$. Ottaway (81) was the first to show a structural and functional link between 
VIP innervation and lymphocyte function. Substance P also affects lymphocyte function and can increase lymphocyte movement through peripheral lymph nodes. In preliminary experiments Sharkey and co-workers (82) demonstrated that substance P and CGRP can increase lymphocyte movement through the gastrointestinal tract (82). Similarly, capsaicin-treated rats have been shown to respond less vigorously to an antigenic challenge, and substance $\mathrm{P}$ can reverse this effect $(83,84)$. Taken together these findings suggest that neuropeptides may prime cells of the immune system to respond to a challenge, such as inflammatory stimulus, and hence are able to modulate the functional capacity of the immune system.

\section{MODULATION OF INFLAMMATION USING NEUROACTIVE COMPOUNDS}

Can nerves initiate or maintain the inflammatory state once it has been initiated? This is an important question because it may lead to novel therapeutic strategies for IBD management. Recent evidence in humans and animals broadly supports the idea of nervous involvement in the inflammatory process. In 1985 the alpha 2 -adrenergic agonist clonidine was used clinically in the treatment of ulcerative colitis (85). Although the results of this study looked promising, others have reported less successful results $(86,87)$, and the side effects of this compound probably preclude it is a widely useful agent. Another compound of interest is nicotine. Treatment of ulcerative colitis patients with nicotine gum or transdermal nicotine patches was found to be effective in some patients $(88,89)$. As with the clonidine studies, the site of action of nicotine has not been determined. Given the enormous number of actions of nicotine centrally

ACKNOWLEDGEMENTS: This work was supported by grants from the Medical Research Council of Canada and the Crohn's and Colitis Foundation of Canada. Keith Sharkey is an Alberta Heritage Foundation for Medical Research (AHFMR) Senior Scholar and Edward Parr is a recipient of an AHFMR studentship.

\section{REFERENCES}

1. Storsteen KA, Kernohan JW, Bargen JA. The myenteric plexus in chronic ulcerative colitis. Surg Gynecol Obstet 1953;97:335-43.

2. Davis DR, Dockerty MB, Mayo CW. The myenteric plexus in regional enteritis: A study of the number of ganglion cells in the ileum in 24 cases. Surg Gynecol Obstet 1955;101:208-16.

3. Shakiroff BGP, Hinton JW. Denervation of the pelvic colon for ulcerative colitis. Surg Forum 1950;1:134-9.

4. Thorek P. Vagotomy for idlopathic ulcerative colitis and regional enteritis. Results in 21 cases. JAMA 1951;145:140-6.

5. Dennis C, Eddy FD, Frykman HM, McCarthy AM, Westover D. The response to vagotomy in idiopathic uncerative colitis and regional enteritis. Ann Surg 1948;128:479-96.

6. Lindgren S, Stewenius J, Sjölund K, Lilja B, Sundkvist G. Autonomic vagal nerve dysfunction in patients with ulcerative colitis. Scand J Gastroenterol 1993;28:638-42.

7. Lindgren S, Lilja B, Rosen I, Sundkvist G. Disturbed autonomic nerve function in patients with Crohn's disease. Scand J Gastroenterol 1991;26:361-6.

8. Furness JB, Costa M. The Enteric Nervous System. Edinburgh: Churchill-Livingstone, 1987.

9. Dockray GJ, Sharkey KA. Neurochemistry of visceral afferent neurones. In: Cervero F, Morrison JFB, eds. Progress in Brain Research, vol 67. Visceral Sensation. Amsterdam: Elsevier Science Publishers, 1986:133-48. and peripherally it is unclear to what extent a peripheral neuromodulatory action is a factor in its effects.

Another class of drugs that have been reported to be beneficial are local anesthetics. Björck et al $(90,91)$ reported that topical lidocaine improves the histological and clinical appearance of proctitis and proctosigmoiditis. Their findings were confirmed and extended by McCafferty and colleagues (92) in a controlled study of the effects of lidocaine in TNBS-induced colitis in rats. McCafferty et al observed that pretreatment of rats with lidocaine reduced the severity of colitis and that lidocaine treatment after inflammation was also effective in reducing disease severity. It is clear that local anesthetics can have actions other than to block conduction of nervous impulses although this mechanism is an appealing one for future studies.

\section{SUMMARY}

The role of the ENS in intestinal inflammation has been established. At this stage there are more questions than answers regarding how ENS is involved and to what extent alterations in structure or neuronal phenotype contribute to IBD pathogenesis. Many of the functional disturbances observed in IBD are likely due to an alteration in the ENS, either structurally through disruptions of nerve-target relationships or by modifications of neurotransmitters or their receptors. Careful studies that investigate the effects of intestinal inflammation on the ENS at the cellular and molecular level are required to achieve a complete understanding of these complex diseases. Finally, it appears that the ENS may be a potential therapeutic target in IBD and that neuroactive drugs that act locally can represent useful agents in IBD management.

10. Holzer P. Capsaicin: Cellular targets, mechanisms of action, and selectivity for thin sensory neurons. Pharmacol Rev 1991;43:143-201.

11. Maggi CA. Capsaicin-sensitive nerves in the gastrointestinal tract. Arch Int Pharmacodyn 1990;303:157-66.

12. Sharkey KA. Substance $P$ and calcitonin gene-related peptide (CGRP) in gastrointestinal inflaumation. Ann NY Acad Sci 1992;664:425-42.

13. Chahl LA, Szolcsanyi J, Lembeck F, eds. Antidromic Vasodilatation and Neurogenic Inflammation. Budapest: Akademiai Kiado, 1984.

14. Costa M, Furness JB, Gibbins IL. Chemical coding of enteric neurons. Prog Brain Res 1986;86:217-40.

15. Bornstein JC, Furness JB. Enteric neurons and their chemical coding. In: Holle GE, Wood JD, eds. Advances in the Innervation of the Gastrointestinal Tract. Amsterdam: Excerpta Medica, 1992:101-14.

16. Costa M, Brookes S, Watermam S, Mayo R. Enteric neuronal circuitry and transmitters controlling intestinal motor function. In: Holle GE, Wood JD, eds. Advances in the Innervation of the Gastrointestinal Tract. Amsterdam: Excerpta Medica, 1992:115-24.

17. Bornstein JC, Furness JB. Correlated electrophysiological and histochemical studies of submucous neurons and their contribution to understanding enteric neural circuits. J Auton Nerv Syst 1988;25:1-13.

18. Sharkey KA, Coggins PJ, Tetzlaff W, Zwiers H, Bisby MA, Davison JS Distribution of growth-associated protein B-50 (GAP-43) in the mammalian enteric nervous system. Neuroscience 1990;38:13-20.

19. Parr EJ, Sharkey KA. The use of constitutive nuclear oncoproteins to count neurons in the enteric nervous system of the guinea-pig. Cell Tissue Res 1994;277:325-31.

20. Parr EJ, Gibson AW, Sharkey KA. C-myc antigens in the mammalian enteric nervous system. Neuroscience 1994;58:807-16.

21. Payan DG. Neuropeptides and inflammation: The role of substance $P$. Ann Rev Med 1989;40:341-52.

22. Miller MJS, Sadowska-Krowicka H, Jeng AY, et al. Substance P levels 
in experimental ileitis in guinea pigs: Effects of misoprostol. Am J Physiol 1993;265:G321-30.

23. Palmer JM, Greenwood B. Regional content of enteric substance P and vasoactive intestinal peptide during intestinal inflammation in the parasitized ferret. Neuropeptides 1993;25:95-103.

24. Eysselein VE, Reinshagen M, Cominelli F, et al. Calcitonin gene-related peptide and substance $\mathrm{P}$ decrease in the rabbit colon during colitis. A time study. Gastroenterology 1991;101:1211-9.

25. Swain MG, Agro A, Blennerhassett P, Stanisz A, Collins SM. Increased levels of subslance $P$ in the myenteric plexus of trichinella-infected rats. Gastroenterology 1992;102:1913-9.

26. Hurst SM, Stanisz AM, Sharkey KA, Collins SM. Interleukin 1 -induced increase in substance $\mathrm{P}$ in rat myenteric plexus. Gastroenterology 1993;105:1754-60.

27. Sharkey KA, Ihns Y. The effects of experimental ileitis on vasoactive intestinal polypeptide (VIP)-immunoreactivity in the guinea pig Gastroenterology 1993;104:A780. (Abst)

28. Kishimoto S, Kobayashi H, Shimizu S, et al. Changes of colonic vasoactive intestinal peptide and cholinergic activity in rats with chemical colitis. Dig Dis Sci 1992;37:1729-37.

29. Schulte-Bockholt A, Fink JG, Otterson MF, Telford GL, Hopp K, Koch TR. Gene expression of VIP in sigmoid colon from chronic ulcerative colitis (CUC). Gastroenterology 1993;104:A578. (Abst)

30. Eysselein VE, Reinshagen M, Patel A, Davis W, Nast C, Sternini C. Calcitonin gene-related peptide in inflammatory bowel disease and experimentally induced colitis. Ann NY Acad Sci 1992;657:319-27.

31. Evangelista S, Meli A. Influence of capsaicin-sensitive fibres on experimentally-induced colitis in rats. J Pharm Pharmacol 1989;41:574-5.

32. Karmeli F, Eliakim R, Rachmilewitz D. Capsaicin pretreatment augments mucosal damage in acetic acid colitis indicating the role of capsaicin sensitive afferent neurons in maintaining colonic mucosal integrity. Gastroenterology 1993;104:A833. (Abst)

33. Domek MJ, Blackman E, Vidrich A, Kao J, Baker M, Leung FW. Capsaicin pretreatment increases severity of dextran sulfate sodium (DSS)-induced colonic damage in rats. Gastroenterology 1993;104:A71. (Abst).

34. Crowe SE, Sestini P, Perdue MH. Allergic reactions of rat jejenual mucosa. Ion transport responses to luminal antigen and inflammatory mediators. Gastroenterology 1990;99:74-82.

35. MacNaughton WK, Leach KE, Prud'homme-Lalonde L, Ho W, Sharkey KA. Ionizing radiation reduces neurally evoked electrolyte transport in rat ileum through a mast cell-dependent mechanism. Gastroenterology 1994;106:324-35.

36. LaMont JT. Mucus: the front line of intestinal mucosal defense. Ann NY Acad Sci 1992;664:190-201.

37. Moore BA, Sharkey KA, Mantle M. Neural mediation of cholera toxin-induced mucin secretion in the rat small intestine. Am J Physiol 1993;265:G1050-6.

38. Laporte JL, Dauge-Geffroy MC, Chariot J, Roze C, Potet F. [Sensory fibers sensitive to capsaicin can modulate secretion of the duodenal mucus. A morphometric study in rats.] Gastroenterol Clin Biol 1993; 17:535-41.

39. Martinolle JP, Moré J, Dubech N, Garcia-Villar R. Inverse regulation of - and -adrenoceptors during trinitrobenzenesulfonic acid (TNB)-induced inflammation in guinea-pig small intestine. Life Sci 1993;52:1499-508.

40. Collins SM, Blennerhassett PA, Blennerhassett MG, Vermillion DL. Impaired acetylcholine release from the myenteric plexus of Trichinella-infected rats. Am J Physiol 1989;257:G898-903.

41. Swain MG, Blennerhassett PA, Collins SM. Impaired sympathetic nerve function in the inflamed rat intestine. Gastroenterology 1991;100:675-82.

42. Collins SM, Hurst SM, Main C, et al. Effect of inflammation of enteric nerves: Cytokine-induced changes in neurotransmitter content and release. Ann NY Acad Sci 1992;664:415-24.

43. Palmer JM. Immunodulation of electrical and synaptic behavior of myenteric neurons of guinea pig small intestine during infection with Trichinella spiralis. In: Collins SM, Snape WJ, eds. Effects of Immune Cells and Inflammation on Smooth Muscle and Enteric Nerves. Boca Raton: CRC Press, 1990:181-95.

44. Wood JD. Histamine signals in enteric neuroimmune interactions. Ann NY Acad Sci 1992:664:275-83.

45. Frieling T. Different types of stimuli evoke spike discharge in submucous neurons of the large intestine driving cyclical chloride secretion. In: Holle GE, Wood JD, eds. Advances in the Innervation of the Gastrointestinal Tract. Amsterdam: Excerta Medica, 1992:425-31.

46. Gabella G. On the plasticity of form and structure of enteric ganglia. J Auton Nerv Syst 1990;30:S59-66.

47. Poncino A, Geuna S, Scherini E, Giacobini Robecchi MG, Filogamo G. DNA synthesis experimentally induced in neurons: tetraploidy or hyperdiploidy? Int J Dev Neurosci 1990;8:621-3.

48. Siemers PT, Dobbins WO. The Meissner plexus in Crohn's disease of the colon. Surg Gynecol Obstet 1974;138:39-42.

49. Reynolds BA, Weiss S. Generation of neurons and astrocytes from isolated cells of the adult mammalian central nervous system. Science 1992;255:1707-10.

50. Dvorak AM, Osage JE, Monohan RA, Dickersin GR. Crohn's disease: Transmission electron microscopic studies. III. Target tissues. Proliferation of and injury to smooth muscle and the autonomic nervous system. Hum Pathol 1980;11:620-34.

51. Steinhoff MM, Kodner IJ, DeSchryver Kecskemeti K. Axonal degeneration/necrosis: a possible ultrastructural marker for Crohn's disease. Mod Pathol 1988;1:182-7.

52. Dvorak AM, Onderdonk AB, McLeod RS, et al. Axonal necrosis of enteric autonomic nerves in continent ileal pouches: Possible implications for pathogenesis of Crohn's disease. Ann Surg 1993;217:260-71.

53. Geboes K, Rutgeerts P, Ectors N, et al. Major histocompatibility class II expression on the small intestinal nervous system in Crohn's disease. Gastroenterology 1992;103:439-47.

54. Strobach RS, Ross AH, Markin RS, Zetterman RK, Linder J. Neural patterns in inflammatory bowel disease: An immunohistochemical survey. Mod Pathol 1990;3:488-93.

55. O'Morain C, Bishop AE, McGregor GP, et al. Vasoactive intestinal peptide concentrations and immunocytochemical studies in rectal biopsies from patients with inflammatory bowel disease. Gut 1984;25:57-61.

56. Bishop AE, Polak JM, Bryant MG, Bloom SR, Hamilton S. Abnormalities of vasoactive intestinal polypeptide-containing nerves in Crohn's disease. Gastroenterology 1980;79:853-60.

57. Sjolund K, Schaffalitzky de Muckadell OB, Fahrenkrug J, Hakanson R, Peterson BG, Sundler F. Peptide-containing nerve fibres in the gut wall in Crohn's disease. Gut 1983;24:724-33.

58. Mazumdar S, Das KM. Immunocytochemical localization of vasoactive intestinal peptide and substance $P$ in the colon from normal subjects and patients with inflammatory bowel disease. Am J Gastroenterol 1992;87:176-81.

59. Koch TR, Carney JA, Go VLW, Szurszewski JH. Altered inhibitory innervation of circular smooth muscle in Crohn's colitis. Association with decreased vasoactive intestinal polypeptide levels. Gastroenterology 1990;98:1437-44.

60. Kubota Y, Petras RE, Ottaway CA, Tubbs RR, Farmer RG, Fiocchi C. Colonic vasoactive intestinal peptide nerves in inflammatory bowel disease. Gastroenterology 1992;102:1242-51.

61. Koch TR, Carney JA, Go VLW. Distribution and quantitation of gut neuropeptides in normal intestine and inflammatory bowel diseases. Dig Dis Sci 1987;32:369-76.

62. Duffy LC, Zielezny MA, Riepenhoff Talty M, et al. Vasoactive intestinal peptide as a laboratory supplement to clinical activity index in inflammatory bowel disease. Dig Dis Sci 1989;34:1528-35.

63. Goldin E, Karmeli F, Selinger Z, Rachmilewitz D. Colonic substance P levels are increased in ulcerative colitis and decreased in chronic severe constipation. Dig Dis Sci 1989;34:754-57.

64. Bernstein CN, Robert ME, Eysselein VE. Rectal substance P concentrations are increased in ulcerative colitis but not in Crohn's disease. Am J Gastroenterol 1993;88:908-13.

65. Mantyh PW, Catton MD, Boehmer CG, et al. Receptors for sensory neuropeptides in human inflammatory diseases: Implications for the effector role of sensory neurons. Peptides 1989;10:627-45.

66. Watanabe T, Kubota Y, Sawada T, Muto T. Distribution and quantification of somatostatin in inflammatory disease. Dis Colon Rectum 1992;35:488-94.

67. Koch TR, Carney JA, Morris VA, Go VLW. Somatostatin in the idiopathic inflammatory bowel diseases. Dis Colon Rectum 1988;31:198-203.

68. Koch TR, Cave DR, Ford H, Kirsner J. Histofluorescent and radioenzymatic analysis of colonic catecholamines in man. J Auton Nerv Syst 1984;11:383-91.

69. Kyösola K, Penttilä O, Salaspuro M. Rectal mucosal adrenergic 
innervation and enterochromaffin cells in ulcerative colitis and irritable colon. Scand J Gastroenterol 1977;12:363-7.

70. Penttilä O, Kyösola K, Klinge E, Ahonen A, Tallqvist G. Studies of rectal mucosal catecholamines in ulcerative colitis. Ann Clin Res 1975;7:32-6.

71. Geboes K, Mebis J, Rutgeerts P, Ectors N, Vantrappen G. Demonstration of nitric oxide positive neurons in Crohn's disease. Gastroenterology 1993;104:A705. (Abst)

72. Stead RH, Tomioka M, Quinonez G, Simon GT, Felten SY, Bienenstock J. Intestinal mucosal mast cells in normal and nematode-infected rat intestines are in intimate contact with peptidergic nerves. Proc Natl Acad Sci USA 1987;84:2975-9.

73. Stead RH, Dixon MF, Bramwell NH, Riddell RH, Bienenstock J. Mast cells are closely apposed to nerves in the human gastrointestinal mucosa. Gastroenterology 1989;97:575-85.

74. Stead RH. Nerve remodelling during intestinal inflammation. Ann NY Acad Sci 1992;664:443-55.

75. Dvorak AM, McLeod RS, Onderdonk AB, et al. Human gut mucosal mast cells: Ultrastructural observations and anatomic variation in mast cell-nerve associations in vivo. Int Arch Allergy Appl Immunol 1992;98:158-68.

76. Mikkelsen HB, Rumessen JJ. Characterization of macrophage-like cells in the external layers of human small and large intestine. Cell Tissue Res 1992;270:273-9.

77. Dvorak AM. Ultrastructure of human gastrointestinal system. Interactions among mast cells, eosinophils, nerves and muscle in human disease. In: Collins SM, Snape WJ, eds. Effects of Immune Cells and Inflammation on Smooth Muscle and Enteric Nerves. Boca Raton: CRC Press, 1990:139-66.

78. Arizono N, Matsuda S, Hattori T, Kojima Y, Maeda T, Galli SJ. Anatomical variation in mast cell nerve associations in the rat small intestine, heart, lung, and skin. Similarities of distances between neural processes and mast cells, eosinophils, or plasma cells in the jejunal lamina propria. Lab Invest 1990;62:626-34.

79. Weihe E, Nohr D, Michel S, et al. Molecular anatomy of the neuro-immune connection. Int J Neurosci 1991;59:1-23.
80. Ottaway CA. Neuroimmunomodulation in the intestinal mucosa. Gastroenterol Clin North Am 1991;20:511-29.

81. Ottaway CA. Vasoactive intestinal peptide as a modulator of lymphocyte and immune function. Ann NY Acad Sci 1988;527:486-500

82. Sharkey KA, Kirk DR, Graham TL. Substance P and CGRP modify lymphocyte output from the mesenteric lymphatic duct of the rat. Gastroenterology 1992;102:A757. (Abst)

83. Nilsson G, Ahlstedt S. Altered lymphocyte proliferation of immunized rats after neurological manipulation with capsaicin. Int J Immunopharmacol 1988;10:747-51.

84. Helme RD, Eglezos A, Dandie GW, Andrews PV, Boyd RL. The effect of substance $\mathrm{P}$ on the regional lymph node antibody response to antigenic stimulation in capsacin-retreated rats. J Immunol 1987;139:3470-3.

85. Lechin F, van der Dijs B, Insausti CL, et al. Treatment of ulcerative colitis with clonidine. J Clin Pharmacol 1985;25:255-62.

86. Sutherland LR. Clonidine in the treatment of ulcerative colitis. Can J Gastroenterol 1988;2(Suppl A):53A-6A.

87. Melander M, Almer S, Strom M. Clonidine in ulcerative colitis and proctitis. J Intern Med 1993;233:93-4. (Lett)

88. Lashner BA, Hanauer SB, Silverstein MD. Testing nicotine gum for ulcerative colitis patients. Experience with single-patient trials. Dig Dis Sci 1990;35:827-32.

89. Pullan RD, Ganesh S, Mani V, et al. Transdermal nicotine treatment for ulcerative colitis: A controlled trial. Gastroenterology 1993;104:A765. (Abst)

90. Björck S, Dahlström A, Ahlman H. Topical treatment of ulcerative proctitis with lidocaine. Scand J Gastroenterol 1989;24:1061-72.

91. Björck S, Dahlström A, Johansson L, Ahlman H. Treatment of the mucosa with local anaesthetics in ulcerative colitis. Agents Actions 1992;35(Suppl):C60-72.

92. McCafferty D-M, Sharkey KA, Wallace JL. Beneficial effects of local or systemic lidocaine in experimental colitis. Am J Physiol 1994;266:G560-7. 


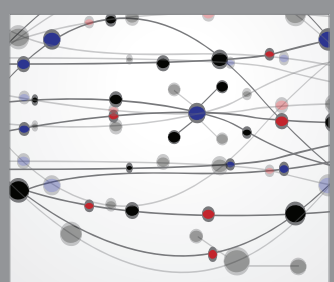

The Scientific World Journal
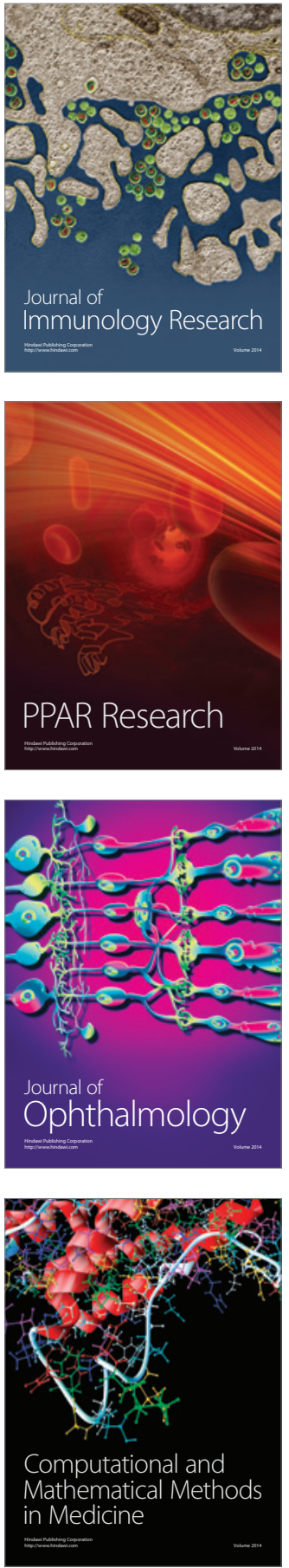

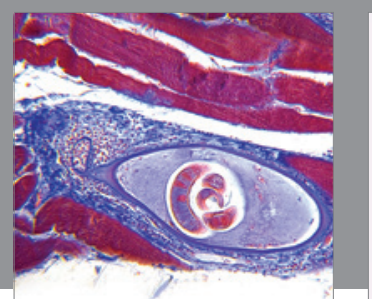

Gastroenterology Research and Practice

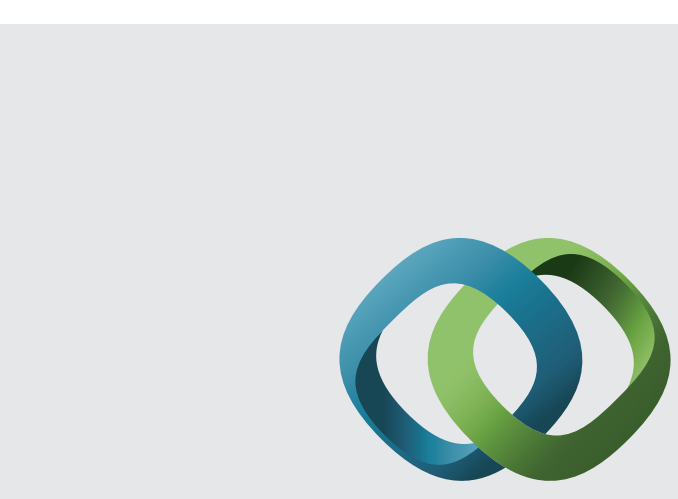

\section{Hindawi}

Submit your manuscripts at

http://www.hindawi.com
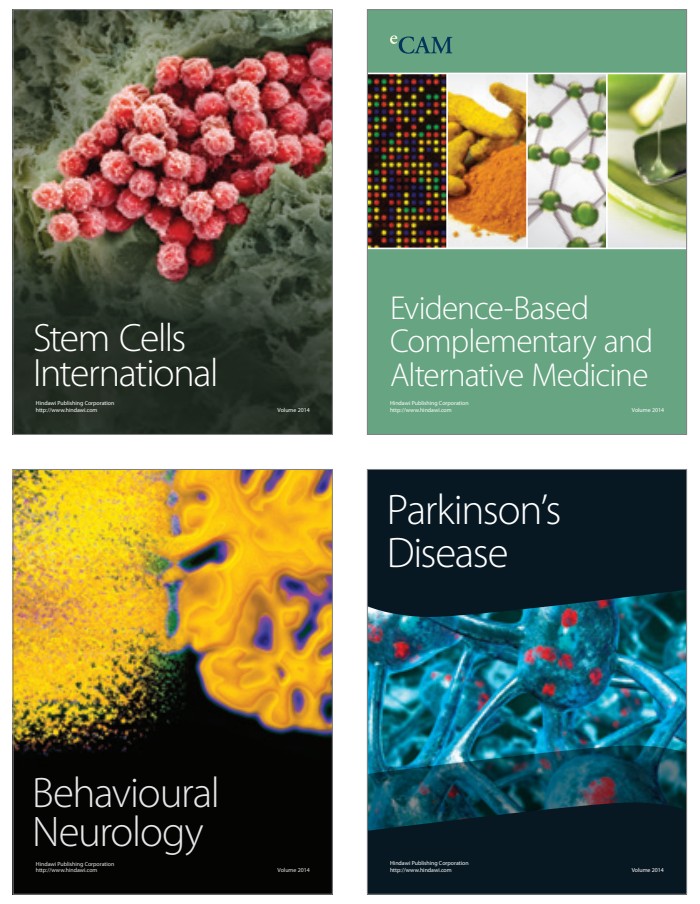
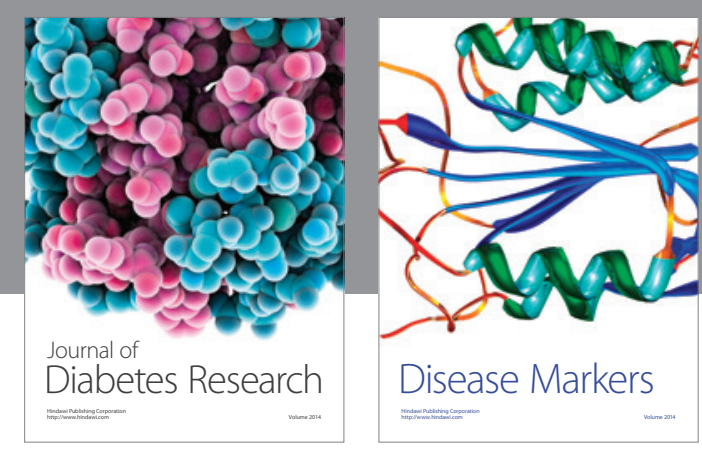

Disease Markers
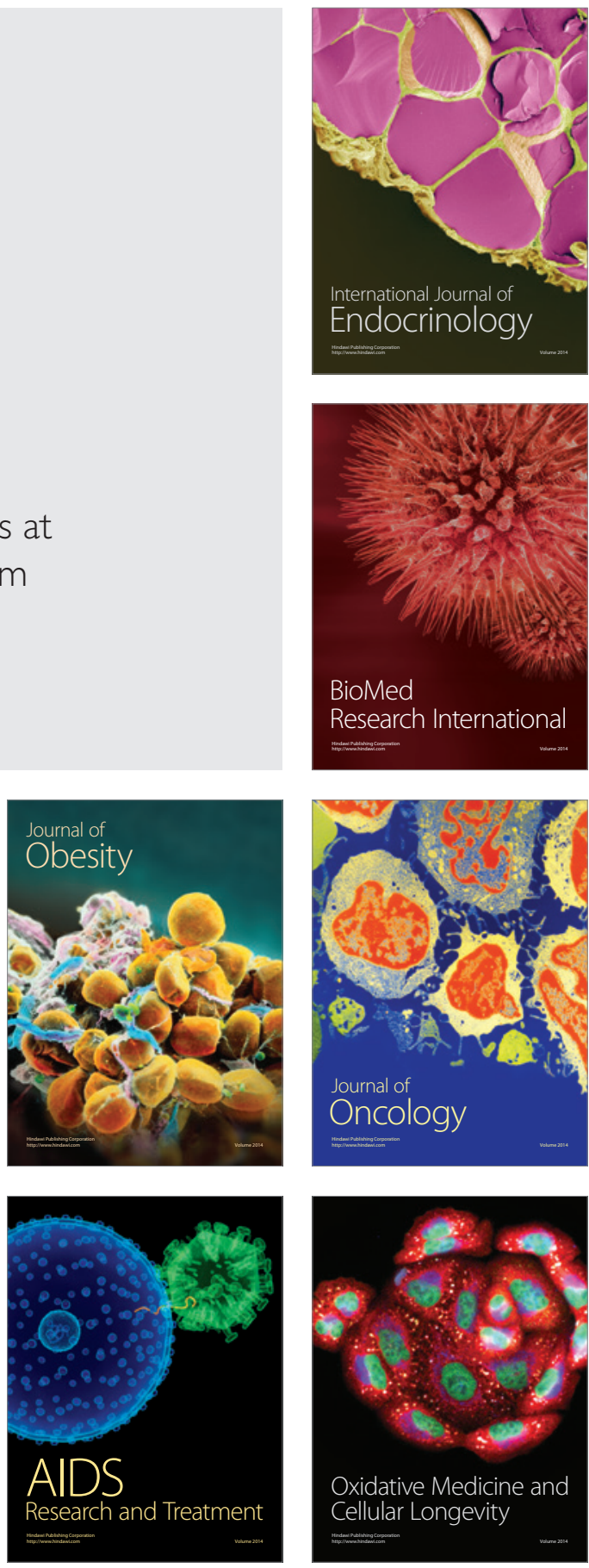